\title{
The Shift of Staple Food from Sago to Rice: A Study about Food Security and Indigenous Communities
}

\author{
Lengga Pradipta
}

Research Center for Population, Indonesian Institute of Sciences (LIPI)

Corresponding Author: lengga.pradipta@gmail.com

ARTICLE INFO
Publication Info:
Research Article
How to cite:
Pradipta, L. (2019). The Shift of
Staple Food from Sago to Rice: A
Study about Food Security and
Indigenous Communities. Society,
7(1), 37-47.

DOI : 10.33019/society.v7i1.76

Copyright (C) 2019. Owned by Author(s), published by Society

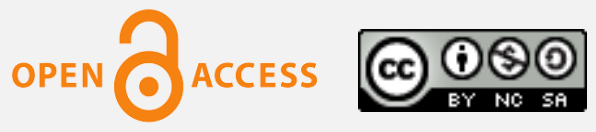

This is an open access article.

\section{License: Attribution- NonCommercial-ShareAlike (CC BY-NC-SA)}

\begin{abstract}
Food security is still becoming a crucial issue in developing countries nowadays, either in urban or rural areas. There are many factors triggered this condition, such as the increase in population pressure and conflict, privatization and changing tenure arrangements, poverty, social differentiation and also environmental degradation. It's undeniable that food security is a multidimensional problem, especially for people who lived in rural or isolated areas. In Mentawai Islands, a district located in the western part of Indonesia, the indigenous people depend on forest product (sago) as their main source of food. However, since 2012, the government has destroyed their food culture by establishing the 'National Food Security Improvement Program' and conducting the agricultural intensification as well as establishing 600 hectares of new rice fields in six sub - districts; South Pagai, North Pagai, Sikakap, South Sipora, North Sipora, and South Siberut. This study is conducted comprehensively using the Food Security and Vulnerability Analysis (FSVA) to understand and describe the exact profiles of food-insecurities and vulnerable households. Furthermore, it also identified the risks and vulnerabilities of food consumption in Mentawai communities. Findings depict that shifting or transforming the food culture from sago to rice is a serious issue because socio-cultural aspects influence it and surely the government has to make a parallel policy that can accommodate the people needs, not only prioritize the national development agenda.
\end{abstract}

Keywords: Food Security; Indigenous Communities; Mentawai Islands 


\section{The Shift of Staple Food from Sago to Rice: A Study about Food Security and Indigenous Communities}

\section{Introduction}

One of the biggest issues faced by developing countries is providing proper food for community, both urban and rural communities. In the context of the rural community, the problem is commonly caused by the scarcity of natural resources, in this case, "food". It is also difficult to access food because of its agricultural condition. Furthermore, internal factors, such as the increase in population pressure and conflict, privatization and changing tenure arrangements, poverty, social differentiation, and environmental degradation have affected the type, quality, accessibility and reliability of food ${ }^{1}$.

As stated at the World Food Summit in 1996, managing the natural resources, especially food, should be based on the participatory approach, involving community, planners and also policy makers. Involving community is a formula and strategic way to inform them about food demand and it can guide them to maintain or even sustain the natural resources (Braun, 2014). All the information related to community demand noted by the planners and policy makers as the important points to consider the formulation of the policies, rules and project arrangements. Demanding responsive project that involve community, it can create the sense of belonging and contribute to the project sustain.

Many efforts have been established to cope with food provision and malnutrition problems. Many projects also held to secure the food provision for rural communities, whether they are conducted by the government, non-governmental

\footnotetext{
${ }^{1}$ In South Asia and Sub-Saharan Africa, population growth has pushed people to settle in ecologically sensitive area such as hilltops and wetland. It will makes them loss the availability of food and difficult for them to find food in new settlement (Dyson, et.al).
}

organizations (NGOs) and even world organizations such as World Bank and United Nations. As In Bangladesh, Ethiopia, Guatemala and South Africa, they were funded by USAID. On the other hand, In Ecuador, Ghana, Nepal, the Philippines and Zimbabwe were funded under a grant from the U.K Department for International Development (DFID) and IFPRI (Quisumbing, A and McClafferty, B., 2006).

Food provision activities and nutrition in Indonesia are also supported by financial and technical assistance from World Bank, Asian Development Bank and many other agencies. Until now, the food and nutrition issue in Indonesia still focused on physical sector (Quisumbing, Estudillo and Otsuka, 2000).

To enhance the sustainability of the food provision scheme, many agricultural projects, whether facilitated by government or non-governmental organizations (NGOs) have applied participatory approach in the project cycles, including planning, implementation, and also monitoring and evaluating process. Unfortunately, food management is not fully over handed to the community as the beneficiaries. As evaluation has shown, that the past food provision and malnutrition problems supported by aid agencies in Indonesia poorly addressed access equity for the poor community. Regarding to this condition, actually since 2012, Indonesian government has already established the regulation about food security in Act No. 18/2012, where its clearly stated that "food security is the condition which all people, in all households, at all times have sufficient food in both quantity and quality to enable them to live healthy, active, productive and sustainable lives, and that the food is safe, diverse, nutritious, equitably distributed and affordable, and does not conflict with religion, beliefs or culture". But in contra, this regulation is triggered many conflicts in Mentawai Islands. It happened because national government tried to apply

Copyright ( 2019. Owned by Author(s), published by Society. This is an open-access article under CC-BY-NC-SA license. https://doi.org/10.33019/society.v7i1.76 
agricultural intensification and establishing 600 hectares of rice fields in those Islands, but ignoring the crucial needs of people. As a matter of fact, Mentawai people are really depended on forest products as their food, such as sago, yam and cassava. Furthermore, the demographic factor like soil condition, human resources skill to manage the rice fields, as well as the technology that will be applied on did not fit with their life.

Transforming the food culture is a crucial thing and needs to consider socio cultural aspects of the people. The national regulation should be parallel with the culture of indigenous people and also their ecological condition. It is important to ensure the sustainability and security of food, and surely prioritize their basic needs.

\section{Methodology}

Food security is multidimensional problems and requires an analysis of a parameter range which consists of three indicators; aggregate food availability, households' access to food, and individuals' food utilization. Since the complexity, this study was conducted comprehensively using the Food Security and Vulnerability Analysis (FSVA). This analysis was very crucial to understand and describe the exact profiles of food-insecurities in communities or households. Furthermore, this study also identified the risks and vulnerabilities of food consumption in Mentawai communities. Moreover, this study observed facts and situation related to perspective of indigenous people and how they engaged in food provision and security, it was crucial to provide an important insight into a food security situation.
Figure 1. Food security conceptual framework (adapted from WFP, 2009)

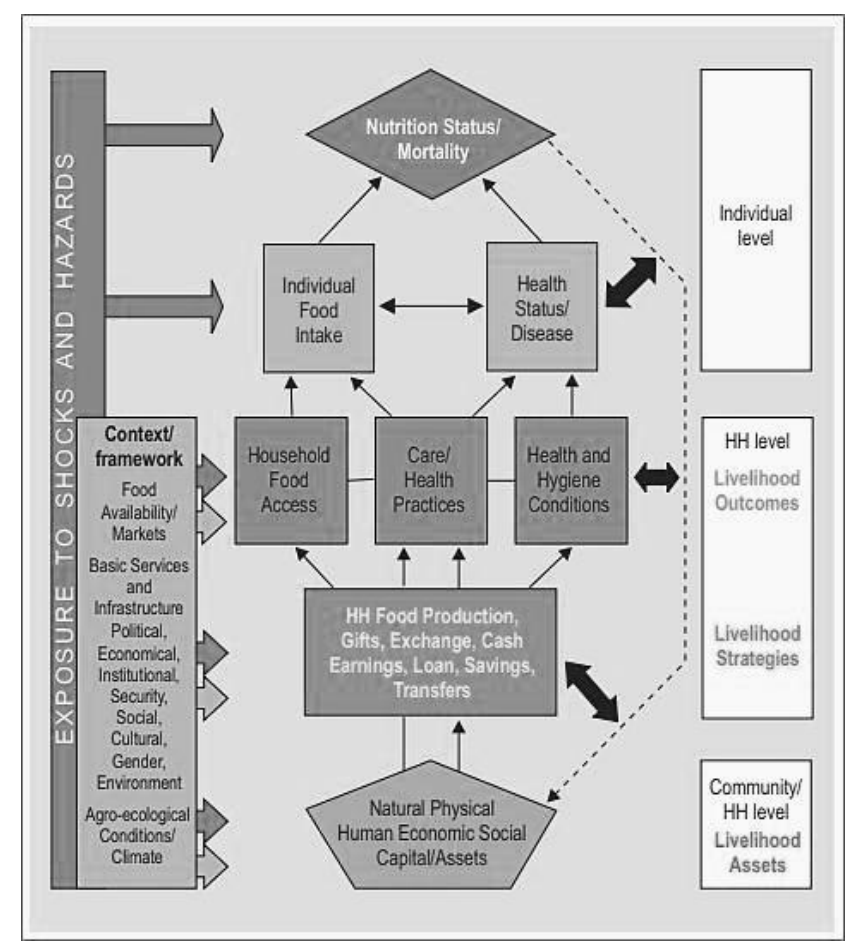

Hence, the primary data were collected through field research. Data collection techniques consisted of field survey in six sub-districts of Mentawai Islands (South Pagai, North Pagai, Sikakap, South Sipora, North Sipora and South Siberut), as well as in-depth interviews with ten indigenous people (including men, women, and Sikerei; indigenous leader) and also focus group discussions. The secondary data were collected from government documents, NGOs report, reports on previous relevant study to the research topic. These data collection supported the Food Security and Vulnerability Analysis (FSVA). As mentioned in previous paragraph, this analysis attemped to describe the profile of the food-insecure and vulnerable households, as well as to identify the causes of food insecurity, risk and vulnerabilities within the community (WFP, 2009). In this study, FSVA was very crucial because it strengthened the findings and results related to food security and how indigenous people were involved and engaged on it. 


\section{The Shift of Staple Food from Sago to Rice: A Study about Food Security and Indigenous Communities}

\section{Result and Discussion}

Defining the food security means there should be a sufficient food condition, and at the same time, the food has to be accessible. Four basic concepts in food security are: sufficiency, temporal considerations, access, and security (Maxwell and Frankenberger, 1992). Sufficiency of food is often a subjective measure; in this issue it was a measure of the frequency and severity of means for coping with food insufficiency.

Sen (1981) also found that access to food is determined by food entitlements, the sum of assets - human, physical or financial which an individual or household can use to acquire food, and the rate at which those assets can be converted into food, either through exchange or production. Security of access is the converse of the risk of entitlement failure; the higher the share of a household's resources devoted to the acquisition of food, the greater the risk of failure (Maxwell and Frankenberger, 1992).

Talking about individual and community condition in gaining the access to food, it cannot be separated with livelihood assets, and it's definitely related to the sustainable livelihood frameworks ${ }^{2}$. The sustainable livelihoods framework is concerned about five essential things; there are human capital, natural capital, financial capital, social capital, and physical capital. One of the outcomes of this framework is to improved food security.

\footnotetext{
2 Sustainable livelihoods: Putting people at the centre of development (Adapted from Chambers, R. and G. Conway (1992) Sustainable rural livelihoods: Practical concepts for the 21st century. IDS Discussion Paper 296. Brighton: IDS) implies that; the livelihoods approach is a way of thinking about the objectives, scope and priorities for development. A specific livelihoods framework and objectives have been developed to assist with implementation, but the approach goes beyond these. In essence it is a way of putting people at the center of development, thereby increasing the effectiveness of development assistance.
}

In Indonesia, improving food security is really depended on knowing who is vulnerable to food, the size of the foodinsecure population, where people live and what makes them vulnerable. Nonetheless, there is also a concerned with the availability of food, started from production, distribution process until consumption. All the cycles are influenced by many factors, such as; climate, soil type, rainfall, agricultural inputs, irrigation systems, technologies and farming practices, and the most crucial one, policy or regulation. In this chapter, there will be holistic explanation about food security in Indonesia, especially in Mentawai islands, and how indigenous communities tied to their food culture, as well as responded the shifting process from sago to rice in their daily life.

\section{Food Security in Indonesia}

Food security issues always have interconnection with many aspects, such as agricultural aspect, social aspect, economic aspect, and even legal aspect. Food security is a complex problem and there are multiple causes for its existence in many developing countries. In Southeast Asia, especially in Indonesia, it is such a vivid condition, that there are many poor people closely related to poverty and hunger. In Indonesia, food is the most fundamental right for everyone and it needs to fulfill every time. It was clearly stated on article (27) of Indonesian Constitutional Law or UUD 1945, and Act No. 7/1996 about food. The lack of food can make a bad impact on human's life (Purwaningsih, 2008).

In Indonesia food always identified as rice. It has been assumed because rice is a kind of staple food for Indonesian. Many experiences had been proven that if the instability of food were happened, it can reflect as an economic crisis. For example in 1997/1998, Indonesia was trapped at the 


\section{The Shift of Staple Food from Sago to Rice: A Study about Food Security and Indigenous Communities}

multidimensional crisis, which was made a tremendous impact to social and national atmosphere. It was contradictive with Indonesia's national development goal, which clearly defined 'food security' as one of the important thing to achieve.

Subsequently, Indonesia has diversification of foods; there are about 400 varieties of fruit, 370 varieties of vegetable, 70 varieties of tuber and 55 varieties of spice. However the main staple food in all over Indonesia is rice; but in some other places people consumes potatoes, maize, cassava, taro and sago. Regarding to this situation, Indonesia has set food policy to achieve self-sufficiency in food production, mainly rice, maize and soybeans. This policy aimed to promote agricultural production and increase the productivity of farmers. Based on the data from Ministry of Agriculture, agricultural sector has been contributed $14.71 \%$ to Indonesian gross domestic product (Kementerian Pertanian, 2015).

Rice, as the worldwide staple food is very dominant crop which grew in more than 13 million hectares of land in Indonesia. Since its massive production, government has tried to decrease the needs for imports and fulfill the indigenous rice consumption. At the other side, Indonesia also has cassava, maize and sago as staple foods, especially in eastern part and also some in western part (like Nias and Mentawai). But unfortunately, there is only few data available about cassava, maize and sago production.

According to the data of National Statistics Agency (BPS), the biggest production of rice or paddy in Indonesia occurs in Java and Sumatra. These two islands have variability in climate and big intensity of rainfall which suit to rice or paddy. From 2004 to 2013 the rice production in Java increased rapidly from 5.71 million ha to 6.47 million ha, while in
Sumatra the amount was increased from 3.16 million ha to 3.52 million ha for a decade (BPS, 2018).

In Sumatra, rice production or paddy reached the highest peak in 2013, while other staple food such as maize, cassava and sweet potatoes remained stable. And as described in the previous paragraph, sago consumption could not be measured as it only consume in Nias and Mentawai. The data about staple food production in Sumatra as show in the graphic below:

Figure 2. Staple food production in Sumatra from 2004 - 2013 (ha)

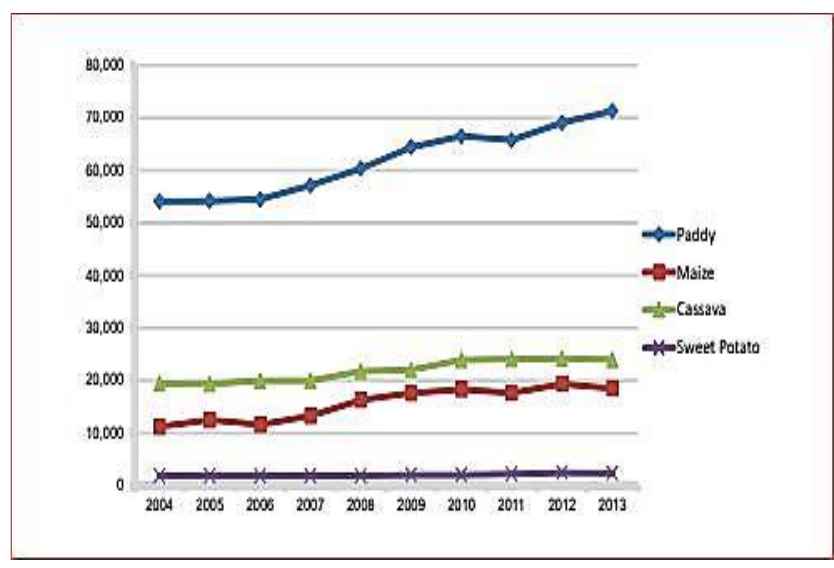

*data from BPS

Even though the production of food increased yearly, yet agricultural sector in Indonesia has to bear with tremendous challenge such as climate change, unpredictable weather and also natural disaster (floods, droughts, etc) which may threatening the progress of food security (LIPI, 2016).

For more than a decade, undeniably, Indonesia has achieved self-sufficiency in rice. It makes the dependency with rice as main source of food was very significant. Although in some parts of Indonesia, people still consume cassava, maize and sago but government wanted to change the food culture. Shifting food culture or food preferences are becoming the big agenda for policy makers. They completely forgot that 
there are some challenges that need to be solved related to food production (especially rice production):

- The land conversion issue has become the biggest challenge, especially in Java, where people tried to convert agricultural land become non agricultural uses (such as for industries, settlements, etc).

- The land degradation that caused by environmental damages or destructions.

- The limited water sources that cause by forest degradation.

- The irrigation systems that is not sufficient for rice or paddy fields.

- Natural disasters such as floods and droughts that may impact on food harvest.

- The farming systems in Indonesia are still not prioritizing the small farmers

Due to many obstacles of food security issue, Indonesia government then set up the Nine Priority Agenda (Nawa Cita) on 2014 which emphasized food sovereignty as a guiding principle to achieve food security. Then those priorities are regulated in the National Medium Term Development Plan (RPJMN) 2015-2019 under five key strategies:

\section{Five strategies in food security}

Increase food availability by enhancing domestic production of key crops (rice, maize, soybean, meat, sugar, chili and onion Improve the quality of food distribution and the accessibility of food

Improve the overall quality and nutritional value of the Indonesian diet

Protect food security through preparedness for natural disasters, mitigating the impact of climate change and preventing infections and diseases in pest or animals

Improve the livelihoods and welfare of farmers, fishermen and other food producers
Access to food is also very crucial in food security issue. Access to food is determined by food entitlements (Sen, 1981), the sum of assets - human, physical or financial - which an individual or household can use to acquire food, and the rate at which those assets can be converted into food, either through exchange or production. Security of access is the converse of the risk of entitlement failure; the higher the share of a household's resources devoted to the acquisition of food, the greater the risk of failure (Maxwell and Frankenberger, 1992). Which means accessing the food is attached to household's ability to obtain sufficient, safe and nutritious food from a combination of sources including own production, stocks, purchases, bartering, gifts, borrowing and food aid.

Food may be physically present in a region, but not accessible to certain households because of some limited access like: a) physical access - market infrastructure, ways of reaching markets, and the functionality of markets; b) economic access - the financial capacity to purchase adequate and nutritious food; and/or c) social access - the social capital needed to engage in informal support mechanisms such as bartering or borrowing, or the presence of social support programs.

Improving and achieving food security are equal to maintaining household purchasing power. To improve purchasing power is a multifaceted effort. Maintaining food prices and controlling inflation especially for food products - are crucial factors. However, a holistic review on agricultural policies found that an emphasis on domestic food production and the provision of various kinds of support to food producers have significant impact on the general population's access to food, not least by maintaining relatively high food prices (OECD, 2015). A holistic review of 
agricultural policies is very useful to analyze the imbalances between strengthening domestic food production and protecting poor consumers. But still, there is awareness that global demand could be another big obstacle in food security issue.

Furthermore, another indicator to ensure food security is its utilization. Food utilization refers to a household's use of the food to which it has access; and an individual's ability to absorb nutrients. Food utilization usually depends on:

- The facilities available for food storage and processing

- Knowledge and practices in food preparation and the feeding of young children and other dependent individuals - including sick and elderly people - which may be impaired by the low education of mothers and other caregivers, cultural beliefs and taboos

- Food-sharing practices within the household

- The health status of the individual, which may be impaired by disease, poor hygiene, water and sanitation and lack of access to health facilities and health care.

These three indicators; availability, access and utilization of food are not applicable in Mentawai case because in that area, those indicators are not always become the parameters. There should be an acknowledgment to community and their food culture, so that we can analyze and understand their food security condition. In the upcoming discussion, an explanation regarding to indigenous people in Mentawai and their food culture will be shown.

\section{Indigenous Communities in Mentawai and Their Food Security}

The Mentawai Islands consists of four main islands; Siberut, Sipora, North Pagai, and South Pagai. The biggest island is Siberut, and it covered 4,090 km2 and consists of two sub districts, north and south Siberut (Persson, 1997). The capital, Tuapejat is located in Sipora. In Mentawai, the population is about 70.000 people but it is very difficult to obtain the reliable statistical information about the archipelago (Nordholt, 2007). The majority of clan that occupied is indigenous people, which count for about 23.000 people in Siberut, and then there are the Minangkabau people who migrated from mainland Sumatra which count for about 2.000 people.

In the New Order era, Mentawai experienced the massive project called 'transmigration'. This project aimed to relocate people from overpopulated islands, so the demographic development could be balanced. More than $70 \%$ of Indonesian population lived in Java, as the main island. And over two decades, there were 170 million inhabitants from Java, Madura, Lombok and Bali were relocated (World Bank, 1999). Transmigration has a long story; it has been started in 1950 which replicated the Dutch colonial government program, and later continued by Indonesian government after 1945, year of independence. Earlier, transmigration has positive purposes, (1) to relocate millions of people from most populated islands such as Java, Bali and Madura to less populated islands, (2) to reduce poverty by providing land and employment opportunities for Indonesian, and (3) to find other resources in those less populated islands. But unfortunately, this programmed seems unsuccessful (DTE Five Years Report, 2011).

The findings also supported by Action in Solidarity with Asia and the Pacific (2019), which stated that the transmigration process in 'outer islands' especially in Mentawai has triggered the conflict among trans-migrants and indigenous people. The native or indigenous people claimed that 
the national government gives the limited access for them, which could be said that contra with the trans-migrants. And on the other hand, indigenous people seem did not obtain sufficient infrastructure to support their lives (such as roads, health facilities, school etc). In the other hand, the land ownership status also become very important, because indigenous people felt that indigenous government did not give their rights and land certificate even though they have legal evidence of their land. More than $60 \%$ of rainforests in Mentawai has been cut-down for transmigration program, and that makes indigenous people lost their homes and their source of food (DTE Five Years Report, 2001). Undeniably, the objective of transmigration may destroy the live of indigenous people. Transmigration made it possible for landless peasant and homeless people from urban Java. But, with this action, they destructed the forest and distributed to environmental degradation in Mentawai. It can be assumed that the transmigration program have failed so far to lower the population pressure in Java, and congers poverty.

Table 1. The transmigration phase in Indonesia

\begin{tabular}{|c|c|c|}
\hline Colonialized Period & $\begin{array}{c}\text { Pelita Period } \\
\text { (New Order Era) } \\
\text { from 1969 - } 1999\end{array}$ & $\begin{array}{l}\text { Reformation Period } \\
(2000-\text { now })\end{array}$ \\
\hline $\begin{array}{l}1^{\text {st }} \text { transmigration occurred in } \\
\text { Lampung (1905 - 1941) } \\
\text { There were about 175.867 } \\
\text { people moved from Java to } \\
\text { Lampung, and it divided } \\
\text { through } 5 \text { phase: } \\
\text { - } 1905-1921 \\
\text { - } 1921 \\
\text { - } 1922 \\
\text { - } 1923 \\
\text { - } 1932-1941\end{array}$ & 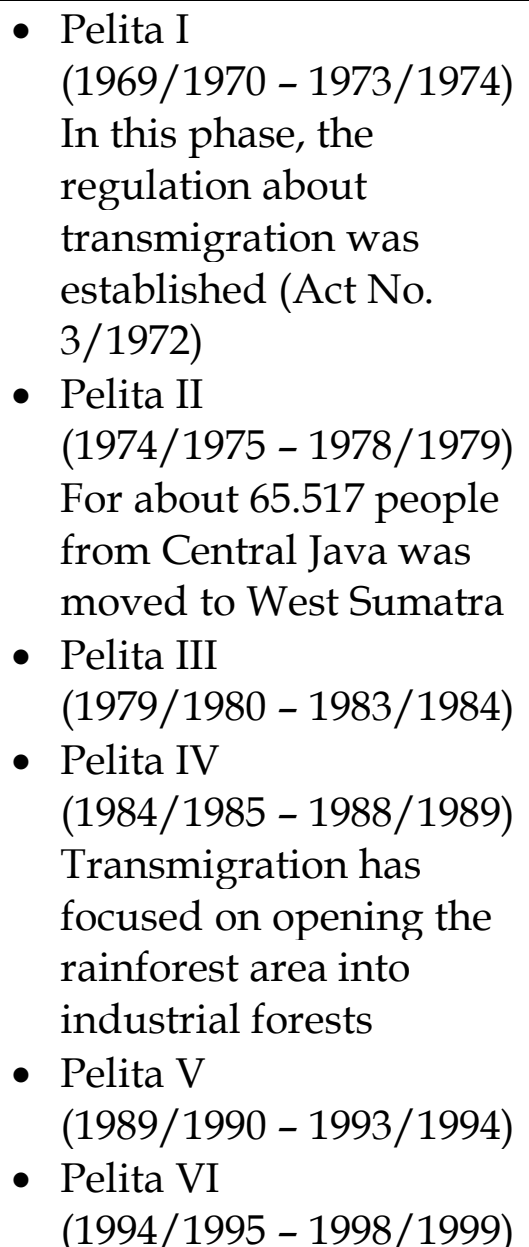 & $\begin{array}{l}\text { Transmigration in this } \\
\text { phase is focusing on } \\
\text { establishing the } \\
\text { independent and } \\
\text { integrated town (Kota } \\
\text { Terpadu Mandiri), so that } \\
\text { it could boost the } \\
\text { regional economy and } \\
\text { development. }\end{array}$ \\
\hline
\end{tabular}

Source: Ministry of Village, Development of Disadvantaged Regions and Transmigration, 2015. 
Based on the field interview that has been conducted by LIPI (2016), it gave the hypotheses that the most difficult part of the transmigration process is always attached with indigenous people who lived in Mentawai. There is a critic about transmigration program, because indigenous people that it's violating their rights. The migrants implied that transmigration program was only about political tools and power.

Figure 3. The settlement of trans migrants in Sipora

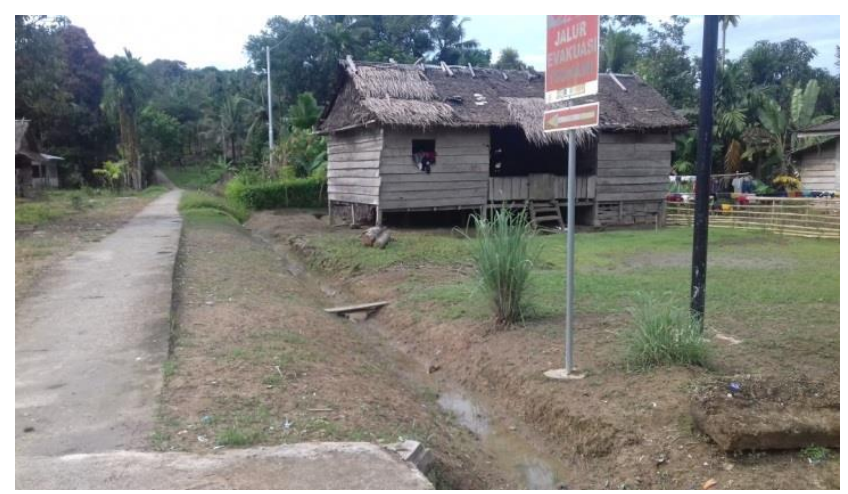

As mentioned in previous part, transmigration program has destroyed the forests as the food sources of indigenous people. It can be seen because the economic system in Mentawai remained slow since most indigenous people do not have money and they just depended on the food product they produce themselves. There is only few people can afford rice and chicken, because mostly they eat the food from forest (such as sago) and ocean (such as fish). Sago, as their main staple food is obtained from the sago pal, and it grows wild in their surroundings. Then they have root crops, bananas, and fruit trees (Persson, 1997). Rice is not a common part of Mentawai people's diet, because it is not cultivated in Mentawai. It has been imported from Padang, the capital city of West Sumatra. Rice is then, for the poorest people too expensive (Johansen, 2008).

Another study conducted by Erwin (2017) argues that most of Mentawai people do not only like to consume rice, they prefer sago. The preference as rice is a prestigious symbolic food, due to its price tag and the challenge of them to reach it. In Mentawai, if a person is able to consume rice a few days in a week, then that person could be classified as the 'haves'. Furthermore, indigenous people value rice not only because they view it as a luxurious food for the wealthy, but also because they value it as being 'modern' and 'developed'. The reasons make them consider sago as a 'primitive' food, which mostly consume by remote Papuans, upstream Dayak or by people in islands a long distance away, such as in Maluku.

Regarding this condition, Indonesian government tried to reinforce food program "Raskin", which is short for 'beras miskin' or 'rice for the poor'. In Mentawai, as elsewhere, that program does not supply the indigenous sago staple food, but rice for poor families. The social signal this program sends is that 'everyone should have rice to eat', reinforcing the message that sago and taro are second grade foods. Sago grows in wet and waterlogged soil. When people cut down a sago tree there are always some saplings in the vicinity which will take its place. After about eight years, the new trees are ready to be harvested. Normally, one good mature sago tree can produce sufficient starch for a family of four or five for about eight to ten weeks.

Figure 4. The household chores to process sago in Mentawai

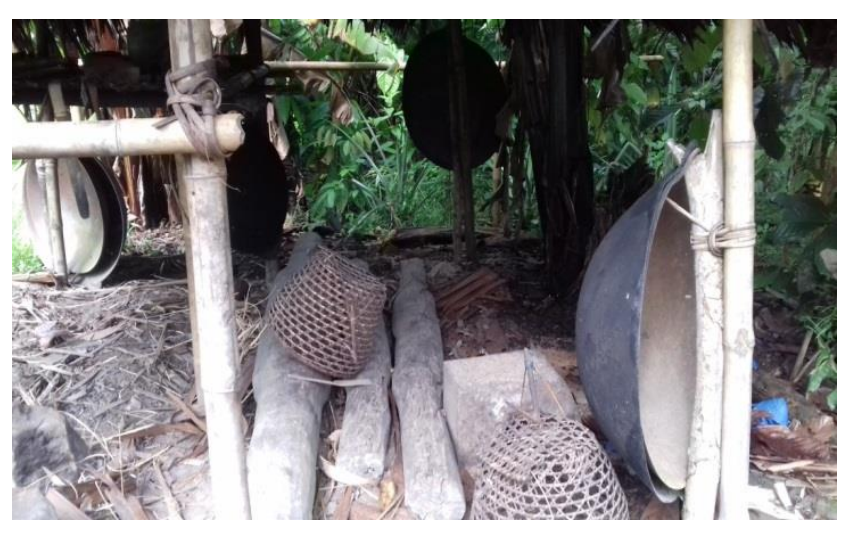

Copyright (C) 2019. Owned by Author(s), published by Society. This is an open-access article under CC-BY-NC-SA license. https://doi.org/10.33019/society.v7i1.76 


\section{The Shift of Staple Food from Sago to Rice: A Study about Food Security and Indigenous Communities}

Besides being a staple food, the sago tree provides other benefits to them. Sago leaves can be used as one of the sturdiest thatched roofs in Indonesia They are a useful wrapper for roasting sago bread sticks or for making tapir, as mentioned above. They are also made a resilient wall material. In addition, the strong sago palm bark can be used for flooring and it burns well in the kitchen fireplace. Parts of sago trees' such as the crown, which does not contain starch, will eventually drop to the ground and in combination with other tree litter, will decay and become the perfect host for sago beetles. The grubs of this beetle are an easy catch and a delicious and much sought after protein source. In sum, the sago palm is a valuable multipurpose plant for the people of Mentawai.

Recently, the local office of the Ministry of Agriculture has assisted in the introduction of rice as main staple food in Mentawai. It makes the existence of sago become smaller. When Mentawai people grow rice as their source of foods, they run risks because it does not suit their culture. Adapting to the new food culture needs more than a decade, especially if the ancestors had introduced sago as the food and philosophy of life (Johansen, 2008). Until now, sago is still valued in the community. In many indigenous rituals, Mentawai people still use sago. Undeniably, it cannot be separated from Mentawai people life, even though government pushed them to change their food culture. And again, shifting or transforming the food culture from sago to rice is a serious problem, because it cannot be separated from socio - cultural aspect of the people. Finally, the consideration to implement the National Food Security Improvement Program has to be parallel with their food culture and also their ecological condition, because sustaining and securing food have to acknowledge the indigenous people needs.

\section{Conclusion}

Food security issue in Mentawai islands is very crucial because even though government tried to apply agricultural intensification by putting rice as the staple food, but they did not consider the indigenous people needs, they still depend on forests product (sago). The missing gap between these two should be solved by using the Food Security and Vulnerability Analysis (FSVA) to understand the exact problems of food security in from households until community level. For Mentawai people, sago is not only their staple food, but it has many functions to support their life. Despite of the good intention and program of national government to shift the food culture should be appreciated, but they are supposed to conduct and in-depth studies related to food culture and society, so that the objective is not against the socio and cultural aspects within indigenous community.

\section{References}

Action in Solidarity with Asia and the Pacific. (1999). Country Reports on Human Rights Practices.

Badan Pusat Statistik. (2018). Ringkasan Eksekutif Luas Panen dan Produksi Beras di Indonesia

DTE, Down to Earth. Five Years Report. (2001). Indonesia's Transmigration Program, An Update. Retrieved from http://www.downtoearthindonesia.org/sites/downtoearthindonesia.org/files/Transmigration \%20update\%202001.pdf

Erwin. (2017). Ketahanan Pangan Rumah Tangga dan Wilayah Berbasis Pangan Lokal Sagu, Keladi dan Pisang di Kabupaten Kepulauan Mentawai. Seminar Nasional Perencanaan 
Pembangunan Inklusif Desa Kota. Universitas Andalas.

Estudillo, J. P., Quisumbing, A. R., \& Otsuka, K. (2000). Income distribution in rice-growing villages during the post-Green Revolution periods: the Philippine case, 1985 and 1998. Agricultural Economics, 25(1), 7184.

Johansen, L. (2008). A Chance of SelfReflection Searching for Information Among People of Mentawai. Master Thesis. Norwegian University of Life Sciences.

Kementerian Pertanian, (2015). Analisis PDB Sektor Pertanian Indonesia.

LIPI. (2016). Kajian Kawasan Hutan Mentawai. Pusat Penelitian Kependudukan Lembaga Ilmu Pengetahuan Indonesia.

Maxwell, S., and Frankenberger, T. R. (1992). Household food security: Concepts, Indicators, Measurements: A technical review. Rome: International Fund for Agricultural Development/United Nations Children's Fund.

Nordholt H. S., Klinken G. V. (2007). Renegotiating Boundaries. indigenous Politics in Post-Suharto Indonesia. Leiden, The Netherlands: KITLV Press.

OECD, O. (2015). Agricultural Policy Monitoring and Evaluation. Retrieved from

https://www.oecd.org/agriculture/t opics/agricultural-policymonitoring-and-evaluation/

Persoon, G. A. (2002). Defining wildness and wilderness: Minangkabau images and actions on Siberut (West Sumatra). Tribal Communities in the Malay World: Historical, Cultural, and Social Perspectives. Singapore: ISEAS [Institute of South East Asian Studies], 439-436.
Purwaningsih, Y. (2008). Ketahanan pangan: situasi, permasalahan, kebijakan, dan pemberdayaan masyarakat. Jurnal Ekonomi Pembangunan: Kajian Masalah Ekonomi dan Pembangunan, 9(1), 1-27.

Quisumbing, M. A. R., \& McClafferty, B. F. (2006). Food security in practice: Using gender research in development. International Food Policy Research Institute Washington, DC

Sen. A. (1981). Poverty and Famines: An Essay on Entitlement and Deprivation. Oxford: Clarendon Press.

von Braun, J. (2014). Food Demand, Natural Resources and Nature. Pontifical Academy of Sciences Extra Series, 41. Retrieved from http://www.pas.va/content/dam/a ccademia/pdf/es41/es41vonbraun.pdf

World Bank. (1999). Annual Report on Indonesian Transmigration.

World Food Program. (2009). Comprehensive Food Security and Vulnerability Analysis. January 2009. First Edition. Citigroup Foundation.

\section{About The Author}

Lengga Pradipta is a junior researcher at the Division of Human Ecology, Research Center for Population, Indonesian Institute of Sciences (LIPI). Joined since February 2015, Lengga has a focus on studies in the fields of Environmental Law and Natural Resources, as well as Gender and Disaster studies. She obtained her Master degree in integrated Natural Resources Management at Andalas University and Asian Institute of Technology Thailand (2007-2010). 